\title{
Relationship between Anion Adsorption and Physicochemical Properties of Aluminum Oxide
}

\author{
Naohito Kawasaki, ${ }^{*, a}$ Fumihiko Ogata, ${ }^{a}$ Kouzou Takahashi, ${ }^{a}$ Mineaki Kabayama, ${ }^{b}$ \\ Kazuaki Kakehi, ${ }^{a}$ and Seiki Tanada ${ }^{a}$
}

${ }^{a}$ School of Pharmacy, Kinki University, 3-4-1 Kowakae, Higashi-Osaka, Osaka 577-8502, Japan and ${ }^{b}$ Tomita Pharmaceutical Co., Ltd., 85-1 Maruyama, Seto-cho, Naruto, Tokushima 771-0360, Japan

(Received December 6, 2007; Accepted March 10, 2008; Published online March 12, 2008)

\begin{abstract}
This study investigated the adsorption capacity and adsorption mechanism of phosphate by calcined aluminum oxide (GB) at temperatures of 200 to $1150^{\circ} \mathrm{C}$. The results showed that GB and GB calcined at a temperature of $200^{\circ} \mathrm{C}$ exhibited almost no adsorption capacity, and GB calcined at temperatures of 300 or $400^{\circ} \mathrm{C}$ exhibited the highest adsorption capacity. After that, adsorption capacity tended to decrease with increasing calcination temperature. The specific surface area and the concentration of surface hydroxyl groups exhibited the highest values in GB calcined at temperatures of 300 and $400^{\circ} \mathrm{C}$. From the above facts, it is conjectured that the specific surface area and concentration of surface hydroxyl groups contribute to the adsorption of phosphate in calcined GB. The results of X-ray diffraction showed that the structure of GB changed drastically at temperatures of 200 to $300^{\circ} \mathrm{C}$ and 900 to $1000^{\circ} \mathrm{C}$. Also, it was evident that phosphate was adsorbed selectively even in complex solution systems containing chloride, nitrate, sulfate, hydrogen carbonate and phosphate ions, and that calcined GB is suitable for adsorption of phosphate. For the adsorption of phosphate, it was found that the optimum $\mathrm{pH}$ is around 4 . When calcined GB is suspended in purified water, it is thought that hydroxyl groups form through dissociative adsorption with water molecules, and that these hydroxyl groups conduct ion exchange with phosphate.
\end{abstract}

Key words — adsorption, aluminum oxide, eutrophication, calcination, phosphate

\section{INTRODUCTION}

In recent years, environmental problems such as air pollution, water pollution and soil pollution have become global in scale. In particular, the occurrence of blue-green algae as water pollution is a cause of foul odors and degradation of scenery. ${ }^{1)}$ Phosphate has a large impact on the growth of algae, and phosphorus is a more serious problem than nitrogen., ${ }^{2,3)}$ In closed sea areas and lakes in particular, the phosphate concentration increases, thereby causing eutrophication, which often leads to the occurrence of red tides or blue-green algae blooms. While phosphate is one of the elements comprising DNA, its constituent ratio compared to the other elements comprising living matter (nitrogen and carbon) is very low: $\mathrm{P}: \mathrm{N}: \mathrm{C}=1: 15: 80 .{ }^{4}$ ) The phosphorus concentration that stimulates algae reproduction is

\footnotetext{
*To whom correspondence should be addressed: School of Pharmacy, Kinki University, 3-4-1 Kowakae, Higashi-Osaka, Osaka 577-8502, Japan. Tel.: +81-6-6730-5880 (Ext. 5556); Fax: +81-6-6721-2505; E-mail: kawasaki@ phar.kindai.ac.jp
}

said to be about $0.03 \mathrm{mg} / 1$. $^{2)}$ When this level of phosphate is released into the environment, the result is the abnormal occurrence of phytoplankton.

The decomposition period of phosphate in the ocean is approximately 160000 years, ${ }^{5)}$ and the cycle of phosphate in the natural world is said to be extremely slow - approximately 400 million years. Deposits of phosphate rock in the earth are said to be 14 billion tons, and are expected to be exhausted in 2035.6) Previously, efforts have been made to develop phosphate removal equipment and to recover phosphorus. For example, there are methods $^{7)}$ in which reaction with materials such as calcium, magnesium or iron ions precipitates phosphate, and methods in which phosphate is adsorbed on iron compounds, alumina, ${ }^{8)}$ activated alumina (produced through aluminum sulfate treatment), ${ }^{9)}$ boehmite ${ }^{10)}$ iron hydroxide oxide, ${ }^{11)}$ and yttrium carbonate, ${ }^{12)}$ as well as adsorbtion-based polymer ligand exchange. ${ }^{13)}$ There have also been a number of reports on anion removal. ${ }^{14,15)}$ Using the adsorption method, it is possible to desorb with an alkali aqueous solution after the phosphate has been ad- 
sorbed. At that time, the adsorbent can be reconditioned, and the adsorbate can be recovered as phosphate alkali, which can then be reused. Therefore, this is thought to be a method which is also superior from the perspective of phosphate resource protection.

This research looked at a method by which aluminum oxide (GB) is calcined at different temperatures, and the resulting substance is used to adsorb anions. In this study, the relationship between the physicochemical properties of GB and the adsorption of anions was estimated by the specific surface area or the concentration of hydroxyl groups, the concentration of anions adsorbed at different $\mathrm{pH}$ levels, and the adsorption rate.

\section{MATERIALS AND METHODS}

Materials — GB (GBH-42 M) was purchased from Showa Denko in Japan. Its chemical composition is adhesive moisture $0.23, \mathrm{Al}(\mathrm{OH})_{3}$ 99.6, $\mathrm{Fe}_{2} \mathrm{O}_{3}$ 0.01, $\mathrm{SiO}_{2}$ 0.01, $\mathrm{Na}_{2} \mathrm{O}$ 0.33, and w- $\mathrm{Na}_{2} \mathrm{O}$ 0.05 . Its average particle size is $1.1 \mu \mathrm{m}$, bulk density (light) $0.2 \mathrm{~g} / \mathrm{cm}^{3}$, bulk density (heavy) $0.5 \mathrm{~g} / \mathrm{cm}^{3}$, specific surface area $5 \mathrm{~m}^{2} / \mathrm{g}$, and average moisture absorption capacity $0.90 \%$. In the calcining treatment, $20 \mathrm{~g}$ of GB was placed in a porcelain crucible and kept in a muffle kiln at 200 to $1150^{\circ} \mathrm{C}$ for $2 \mathrm{hr}$. The specific surface area of GB was measured using Flow SorbII 2300 (Micromeritics, Norcross, GA, U.S.A.). A DTG-60AH automatic differential thermal/thermogravimetry measurement unit (Shimazu, Kyoto, Japan) was used for differential thermoanalysis of GB, and a RINT2100 V (Rigaku, Tokyo, Japan) was used for X-ray diffraction analysis.

The surface $\mathrm{pH}$ of GB was measured as follows: approximately $2.0 \mathrm{~g}$ of GB was separately put into $100 \mathrm{ml}$ of deionized water ( $\mathrm{pH} \mathrm{7.0)}$ ) for $2 \mathrm{~min}$, and the $\mathrm{pH}$ in solution was measured with a digital $\mathrm{pH}$ meter (Horiba, Kyoto, Japan).

The concentration of surface hydroxyl groups was found from the amount of fluoride ion adsorption. ${ }^{16)} \mathrm{GB}$ was added to $50 \mathrm{ml}$ of $0.01 \mathrm{~mol} / 1$ sodium fluoride solution, and shaken at $25^{\circ} \mathrm{C}$ for $20 \mathrm{hr}$. The fluoride concentration in the supernatant was measured using DR4000U (HACH, Loveland, CO, U.S.A.) and the amount adsorbed was estimated based on the difference from the initial concentration.

Sodium chloride, sodium sulfate, sodium nitrate and sodium hydrogen carbonate (Wako Pure Chemical Industries, Osaka, Japan) were used to evaluate the effects of other anions in the adsorption of phosphate.

Adsorption of Phosphate — The adsorption rate of phosphate onto GB was measured as follows: GB $(1.0 \mathrm{~g})$ was added to $200 \mathrm{ml}$ of potassium dihydrogen phosphate solution with an initial concentration of $1 \mathrm{mmol} / \mathrm{l}$. After 1, 5, 10, 20, 30, 60, 90, 120, 150 and $180 \mathrm{~min}$, the solution was filtered with $0.45 \mu \mathrm{m}$ filter paper (Advantec Toyo, Tokyo, Japan). The concentration of phosphate was measured, and evaluation was done by finding the amount adsorbed from the difference with the initial concentration of phosphate. The amount of phosphate adsorbed onto GB was measured by the following method: to $50 \mathrm{ml}$ of $1 \mathrm{mmol} / 1$ potassium dihydrogen phosphate solution, $0.1 \mathrm{~g}$ of GB or GB calcined at 200 to $1150^{\circ} \mathrm{C}$ was added and shaken for $15 \mathrm{hr}$. After that, the solution was filtered with $0.45 \mu \mathrm{m}$ filter paper. The concentration of phosphate was measured, and the amount adsorbed was found from the difference in phosphate concentration before and after adsorption. The concentration of phosphate was measured using the Phosphate Test (HACH). The amount of phosphate adsorbed onto GB at equilibrium was calculated from Eq. (1).

$$
q=\frac{\left(C_{0}-C e\right) \cdot V}{1000 \cdot W s}
$$

Here, $q$ is the amount of phosphate adsorbed $\left(\mathrm{mg}-\mathrm{PO}_{4} / \mathrm{g}\right), C_{0}$ is the initial concentration (mg$\left.\mathrm{PO}_{4} / \mathrm{l}\right), \mathrm{Ce}$ is the equilibrium concentration (mg$\left.\mathrm{PO}_{4} / \mathrm{l}\right), V$ is the amount of sample liquid ( $\left.\mathrm{ml}\right)$, and $W s$ is the amount of GB used (g). In order to investigate the saturation amount of phosphate adsorbed onto GB, $0.5 \mathrm{~g}$ of GB was added to $50 \mathrm{ml}$ of $12 \mathrm{mmol} / \mathrm{l}$ potassium dihydrogen phosphate solution. After shaking for $15 \mathrm{hr}$ at $25^{\circ} \mathrm{C}$, the solution was filtered with $0.45 \mu \mathrm{m}$ filter paper, and the concentration of phosphate was measured.

The solution $\mathrm{pH}$ was adjusted to 2-9 using a digital $\mathrm{pH}$ meter together with $1 \mathrm{~mol} / 1$ hydrochloric acid solution, $0.1 \mathrm{~mol} / 1$ hydrochloric acid solution and $0.1 \mathrm{~mol} / 1$ sodium hydroxide solution. GB $(0.1 \mathrm{~g})$ was added to $50 \mathrm{ml}$ of phosphate solution with an initial concentration of $1 \mathrm{mmol} / 1$ after $\mathrm{pH}$ adjustment, and after shaking for $15 \mathrm{hr}$, the solution was filtered with $0.45 \mu \mathrm{m}$ filter paper, and the concentration of phosphate was measured. This method was used to determine the amount of phosphate adsorbed onto GB in solutions with different $\mathrm{pHs}$. 
Selective Adsorption of Anions - In order to evaluate selective adsorption of phosphate onto GB, measurements were taken of the amount of chloride, sulfate and nitrate adsorbed onto $0.1 \mathrm{~g}$ of $\mathrm{GB}$ and calcined GB. A $1 \mathrm{mmol} / 1$ solution of chloride, sulfate and nitrate ions was prepared using sodium chloride, sodium sulfate and sodium nitrate, respectively. GB $(0.1 \mathrm{~g})$ was added to $50 \mathrm{ml}$ of the prepared anion solutions, and after shaking for $15 \mathrm{hr}$, the solutions were filtered with $0.45 \mu \mathrm{m}$ filter paper, and the concentration of the anion was measured. The concentrations of chloride and sulfate ions were measured using DR4000U (HACH), and the concentration of nitrate was measured using the Nitrate Test $(\mathrm{HACH})$. The removal percentage of anion was calculated from the difference between the initial concentration and the equilibrium concentration.

\section{RESULTS AND DISCUSSION}

\section{Properties of Calcined GB}

Figure 1 shows the results of differential thermoanalysis of GB. It is evident from the results of differential thermoanalysis that an endothermic reaction and changes in structure occur near a calcination temperature of $300^{\circ} \mathrm{C}$. That is, it is conjectured that adhesion water evaporates between 200 and $300^{\circ} \mathrm{C}$. The weight also decreases greatly at the same time. The results of X-ray diffraction for calcined GB are shown in Fig. 2. The results show large changes in structure at calcination temperatures between 200 and $300^{\circ} \mathrm{C}$. Large changes in structure are also thought to occur in the range 900 to $1000^{\circ} \mathrm{C}$. Weller ${ }^{17)}$ and Peri ${ }^{18)}$ report that water molecules dissociatively adsorb onto aluminum oxide; dissociative adsorption has also been reported for boehmite. ${ }^{19)}$ The phases from GB to corundum by calcination were reported by Hill et al. ${ }^{20)}$

Table 1 shows the relationship between GB calcination temperature and the specific surface area, the surface $\mathrm{pH}$ and the concentration of surface hydroxyl groups. In these results, the specific surface area increased greatly at a calcination temperature of $300^{\circ} \mathrm{C}$, reached a maximum at a calcination temperature of $400^{\circ} \mathrm{C}$, and then decreased as the calcination temperature rose. Furthermore, the specific surface area decreased greatly at the calcination temperature of $1000^{\circ} \mathrm{C}$. The concentration of surface hydroxyl groups was the highest when the calcination temperature was $400^{\circ} \mathrm{C}$; above $400^{\circ} \mathrm{C}$ it decreased with increasing calcination temperature.

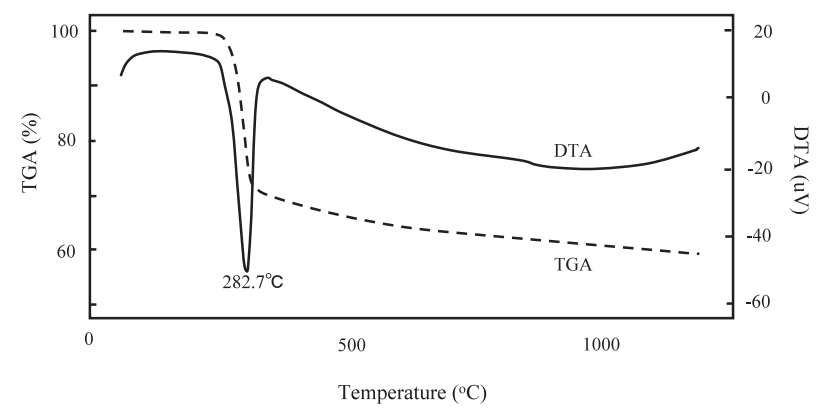

Fig. 1. TG-DTA of GB

Table 1. Specific Surface Area and the Concentration of Hydroxyl Group of GB Calcined at Different Temperatures

\begin{tabular}{cccc}
\hline \hline $\begin{array}{c}\text { Calcination } \\
\text { temperatures } \\
\left({ }^{\circ} \mathrm{C}\right)\end{array}$ & $\begin{array}{c}\text { Specific surface } \\
\text { area }\left(\mathrm{m}^{2} / \mathrm{g}\right)\end{array}$ & $\begin{array}{c}\text { Specific } \\
\mathrm{pH}\end{array}$ & $\begin{array}{c}\text { Concentration of } \\
\text { hydroxyl group } \\
(\mathrm{mmol} / \mathrm{g})\end{array}$ \\
\hline $\begin{array}{c}\text { untreated } \\
200\end{array}$ & 4.2 & 8.7 & 2.7 \\
300 & 253.6 & 9.3 & 2.8 \\
400 & 295.3 & 9.7 & 4.6 \\
500 & 227.3 & 9.8 & 5.0 \\
600 & 176.1 & 9.3 & 4.8 \\
700 & 147.7 & 9.4 & 4.6 \\
800 & 128.1 & 9.6 & 4.2 \\
900 & 95.4 & 9.7 & 3.8 \\
1000 & 36.8 & 10.0 & 3.4 \\
1100 & 20.8 & 10.3 & 1.0 \\
1150 & 17.7 & 10.2 & 1.0 \\
\hline
\end{tabular}

\section{Adsorption of Phosphate}

Figure 3 shows the removal percentage of phosphate by GB as time passes. The kinetic constant was calculated to elucidate the adsorption rate using the formula of the first-order reaction. The kinetic constants of GB calcined at 300 and $1000^{\circ} \mathrm{C}$ measured at $20 \mathrm{~min}$ or less were 0.037 and $0.006 \mathrm{~min}^{-1}$, respectively while those at 30 to $180 \mathrm{~min}$ were 0.013 and $0.002 \mathrm{~min}^{-1}$, respectively. In the results, the removal percentage of phosphate due to GB showed a striking decrease for the first $30 \mathrm{~min}$ for all calcination temperatures; this decrease was more conspicuous as the calcination temperature decreased. After that, there was a smooth decrease as time passed.

Table 2 shows the amount of phosphate adsorbed in a single solution or the saturation amount of phosphate adsorbed onto GB and GB calcined at different temperatures. The results show that GB and GB calcined at $200^{\circ} \mathrm{C}$ adsorb almost no phosphate. A sudden increase in the amount adsorbed was evident for $\mathrm{GB}$ calcined at $300^{\circ} \mathrm{C}$. The solu- 


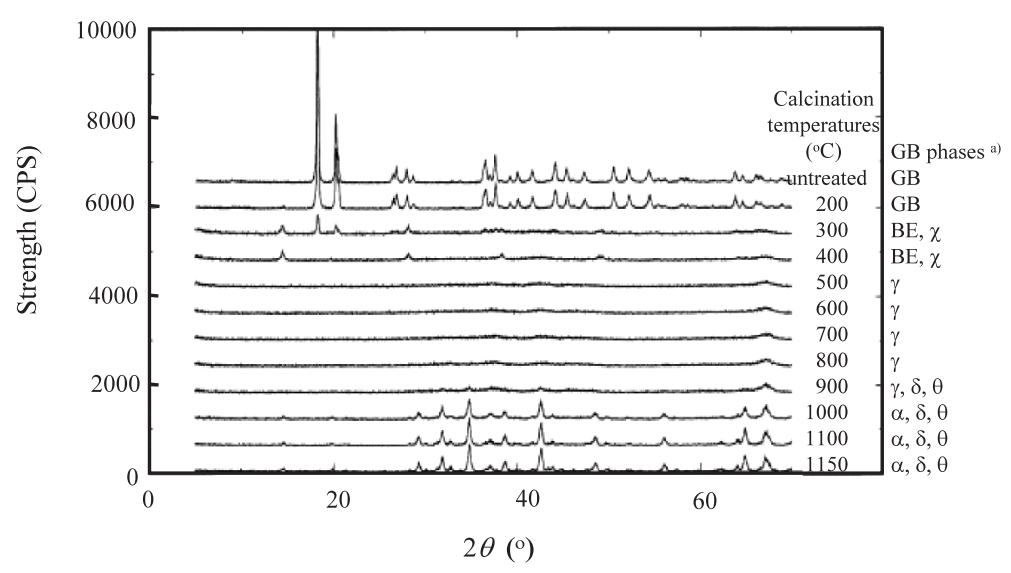

Fig. 2. X-ray Diffraction of GB and GB Calcined at Different Temperatures a) GB phases: Hill et al. reported.

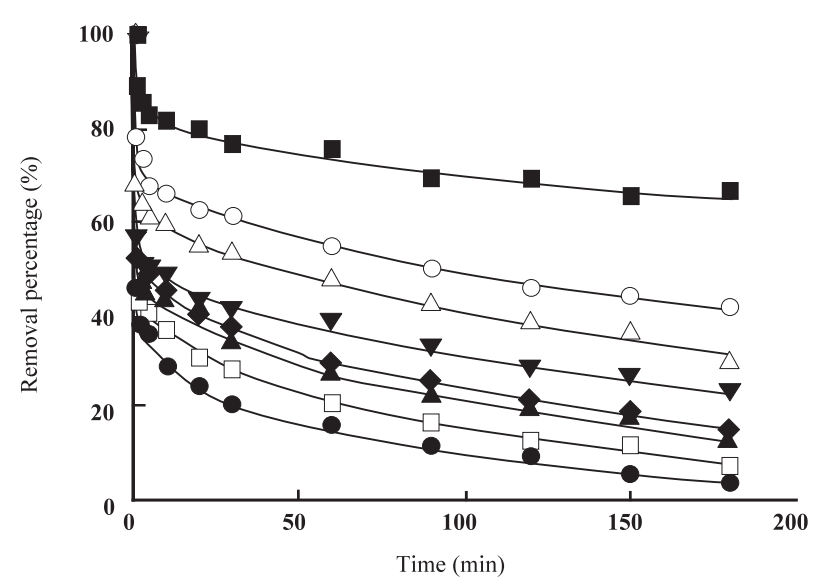

Fig. 3. Removal Percentage of Phosphate onto GB Calcined at Different Temperatures

๑: $300^{\circ} \mathrm{C}, \square: 400^{\circ} \mathrm{C}, \boldsymbol{\Delta}: 500^{\circ} \mathrm{C}, \bullet: 600^{\circ} \mathrm{C}, \boldsymbol{\nabla}: 700^{\circ} \mathrm{C}, \triangle: 800^{\circ} \mathrm{C}$, $\mathrm{O}: 900^{\circ} \mathrm{C}, \mathbf{m}: 1000^{\circ} \mathrm{C}$.

tion $\mathrm{pH}$ after adsorption of phosphate was greater than that before adsorption. This is thought to be due to the surface hydroxyl groups of GB being involved in ion exchange with phosphate. The amount of phosphate adsorbed was the greatest for GB calcined at temperatures of 300 and $400^{\circ} \mathrm{C}$; after that, the amount of phosphate adsorbed decreased with increasing calcination temperature. This same trend was evident for the specific surface area and the concentration of surface hydroxyl groups. It has been reported that, in adsorption onto boehmite - which is also aluminum hydroxide oxide - there is dependence on specific surface area and concentration of surface hydroxyl groups, ${ }^{19)}$ and the specific surface area and the concentration of surface hydroxyl groups are thought to be involved also in the adsorp- tion of phosphate onto GB.

In terms of the saturation amount of phosphate, that adsorbed onto GB or GB calcined at $200^{\circ} \mathrm{C}$ was close to none. That onto GB calcined at temperatures of 300 to $500^{\circ} \mathrm{C}$ was the largest of all, and that onto GB calcined at higher temperatures decreased. The saturation amount of phosphate adsorbed also decreased greatly with calcination temperatures of 900 to $1000^{\circ} \mathrm{C}$.

\section{Selective Adsorption of Phosphate}

Seawater contains many anions. Hence, for the purpose of phosphate recovery using GB, it is critical to evaluate the effects of other anions on phosphate adsorption. The anions in seawater are chloride and sulfate ions, while the salts contained in seawater are sodium chloride (78\%), magnesium chloride $(10 \%)$, magnesium sulfate $(6 \%)$, calcium sulfate $(4 \%)$ and calcium chloride $(2 \%)$. The amounts of chlorine, nitrate, sulfate and phosphate adsorbed onto GB in complex solution are shown in Table 3. The results show that selectivity in adsorption of anions onto GB increases in the sequence: chloride ion $<$ nitrate ion $=$ sulfate ion $<$ phosphate. From these results, it is evident that GB selectively adsorbs phosphate, and is suitable for recovering phosphate from rivers, lakes and seawater. The amount of phosphate adsorbed in complex solution was evaluated in order to evaluate selectivity in adsorption of phosphate onto GB. It was evident from the results that the amount of phosphate adsorbed onto GB in a complex solution was practically the same as that in a single solution; GB selectively adsorbs phosphate in complex solutions without being affected by other anions. 
Table 2. Amount of Phosphate Adsorbed onto Calcined GB at Different Temperatures

\begin{tabular}{cccc}
\hline \hline $\begin{array}{c}\text { Calcination } \\
\text { temperatures } \\
\left({ }^{\circ} \mathrm{C}\right)\end{array}$ & $\begin{array}{c}\text { Amount adsorbed } \\
\left(\mathrm{mg}-\mathrm{PO}_{4} / \mathrm{g}\right)\end{array}$ & $\begin{array}{c}\mathrm{pH} \text { in solution } \\
\text { after adsorption } \\
(\text { Intial concentration: } \\
(\mathrm{pH} \text { before adsorption: }\end{array}$ & $\begin{array}{c}\text { Amount adsorbed } \\
\left(\mathrm{mg}-\mathrm{PO}_{4} / \mathrm{g}\right)\end{array}$ \\
\hline untreated & $0.99 \mathrm{mmol} / \mathrm{l})$ & $4.9)$ & $12 \mathrm{mmol} / \mathrm{l})$ \\
200 & 1.5 & 5.8 & 3.5 \\
300 & 2.5 & 6.0 & 3.0 \\
400 & 28.3 & 7.2 & 56.9 \\
500 & 30.2 & 7.4 & 56.0 \\
600 & 27.1 & 7.4 & 57.0 \\
700 & 24.6 & 7.4 & 51.6 \\
800 & 22.7 & 7.4 & 46.5 \\
900 & 20.0 & 7.0 & 36.4 \\
1000 & 18.1 & 7.0 & 33.1 \\
1100 & 9.6 & 6.5 & 14.5 \\
1150 & 6.6 & 6.4 & 9.0 \\
\hline
\end{tabular}

Table 3. Removal Percentage of Chloride, Nitrate, Sulfate and Phosphate Ions by Calcined GB at Different Temperatures

\begin{tabular}{ccccc}
\hline \hline Calcination & \multicolumn{4}{c}{ Removal percentage (\%) } \\
\cline { 2 - 5 } temperatures & $\begin{array}{c}\text { Chloride } \\
\left({ }^{\circ} \mathrm{C}\right)\end{array}$ & $\begin{array}{c}\text { Nitrate } \\
\text { ion }\end{array}$ & $\begin{array}{c}\text { Sulfate } \\
\text { ion }\end{array}$ & $\begin{array}{c}\text { Phosphate } \\
\text { ion }\end{array}$ \\
\hline untreated & 0.0 & 0.2 & 1.2 & 8.6 \\
200 & 0.0 & 1.5 & 0.8 & 7.7 \\
300 & 0.1 & 0.2 & 5.8 & 53.6 \\
400 & 0.0 & 0.5 & 2.5 & 54.5 \\
500 & 0.0 & 0.3 & 5.3 & 53.2 \\
600 & 0.1 & 0.9 & 1.5 & 48.6 \\
700 & 0.0 & 0.7 & 1.8 & 45.9 \\
800 & 0.0 & 0.0 & 1.3 & 40.9 \\
900 & 0.0 & 0.0 & 0.0 & 39.5 \\
1000 & 0.2 & 0.0 & 0.3 & 16.8 \\
1100 & 0.5 & 0.0 & 0.0 & 16.8 \\
1150 & 0.0 & 0.0 & 0.0 & 11.8 \\
\hline
\end{tabular}

\section{Amount of Phosphate Adsorbed in Different pH Solution}

In general, ion adsorption is affected by $\mathrm{pH}$, and it is important to evaluate phosphate adsorption behavior in aqueous solutions of different $\mathrm{pHs}$. Figure 4 shows the amount of phosphate adsorbed onto GB calcined at temperatures of 300 to $800^{\circ} \mathrm{C}$ in aqueous solutions with different $\mathrm{pHs}$. In the results, the amount of phosphate adsorbed exhibited its highest value in an aqueous solution with acidic conditions ( $\mathrm{pH}$ around 4), and decreased as the $\mathrm{pH}$ rose. This trend was the same, regardless of differences in calcination temperatures. This is thought to be because phosphate replacement to GB is impossible under alkaline conditions. Xu et al. ${ }^{21)}$ report

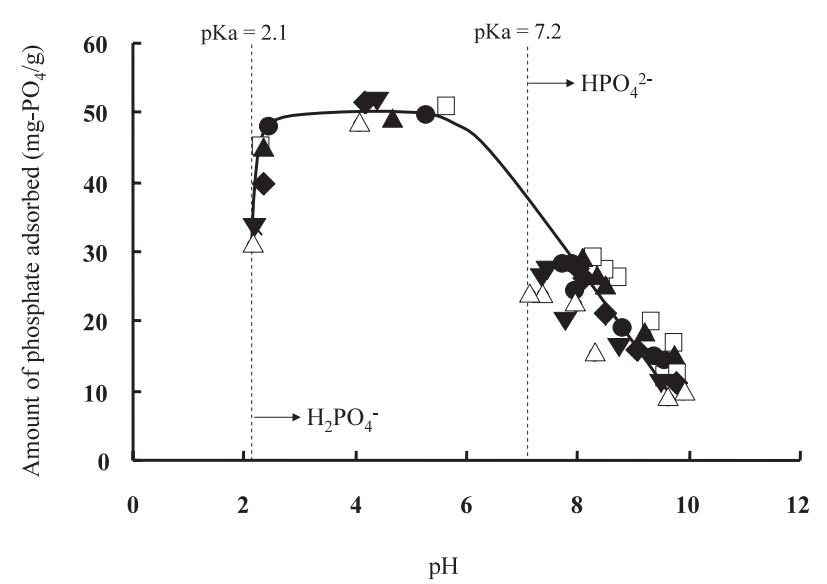

Fig. 4. Amount of Phosphate Adsorbed onto GB Calcined at Different Temperatures in Different $\mathrm{pH}$ Solutions

•: $300^{\circ} \mathrm{C}, \square: 400^{\circ} \mathrm{C}, \mathbf{\Delta}: 500^{\circ} \mathrm{C},: 600^{\circ} \mathrm{C}, \mathbf{\nabla}: 700^{\circ} \mathrm{C}, \triangle: 800^{\circ} \mathrm{C}$.

that, when the initial concentration is $0.64 \mathrm{mmol} / 1$, removal of phosphate by aluminum-supported silaszeolite decreases from $80 \%$ to approximately $40 \%$ from $\mathrm{pH} 2$ to 11 . The molecular formula of aluminum supported silas-zeolite is $\mathrm{Al}(\mathrm{OH})_{3}$, the same as GB. Therefore, GB is also thought to be affected by $\mathrm{pH}$.

This research investigated the adsorption mechanism of phosphate onto the surface of GB calcined at temperatures in the range of 200 to $1150^{\circ} \mathrm{C}$. The results showed that GB does not exhibit adsorption capacity unless it is calcined at $300^{\circ} \mathrm{C}$ or higher. The amount of phosphate adsorbed onto GB calcined at temperatures of 300 to $800^{\circ} \mathrm{C}$ was higher than GB calcined at other calcination temperatures. An adsorbent with adsorption capacity 
for phosphate can be fabricated from calcined GB. It was found that GB selectively adsorbs phosphate, and the adsorption rate is extremely fast. Also, the amount of phosphate adsorbed onto GB is affected by $\mathrm{pH}$, and the amount of phosphate adsorbed onto GB is the highest in aqueous solution under acidic conditions; the adsorption capacity decreases in the alkaline state. It was also found that adsorption of phosphate is not affected by the presence of other anions, and that phosphate is adsorbed selectively onto GB compared to chloride, nitrate, sulfate and hydrogen carbonate ions.

Acknowledgements This project was funded as a "High-Tech Research Center" Project for Private Universities and received a matching fund subsidy from MEXT (Ministry Technology), 2007-2012.

\section{REFERENCES}

1) Inamori, S. and Sudoho, R. (1992) Future aspect and present conditions of water environment and recycle engineering. Jpn. Soc. Precision Eng., 58, 30-37.

2) Sudohu, R. and Inamori, S. (1983) Removal meaning of nitrogen phosphate from sewage and trend to removal technology of them. Jpn. Sewage Works Assoc., 20, 1-12.

3) Yamamoto, T., Hashimoto, S., Matsuda, O. and Tada, T. (1999) Ratio in waters of the seto inland sea, Japan, and the possible factors affecting its fluctuation. Bull. Jpn. Soc. Fish Oceanog., 63, 6-13.

4) Broecker, W. S. (1981) Oceanic Chem. Introduction, Introduction to Oceanographic Chemistry, University of Tokyo Press, Tokyo, p.10.

5) Broecker, W. S. (1981) Oceanic Chem. Introduction, Introduction to Oceanographic Chemistry, University of Tokyo Press, Tokyo, p.19.

6) Kotabe, H. (1987) Present situation and future of phosphate resources. Gypsum \& Lime, 210, 307316.

7) Kobayashi, A., Suzuki, H. and Fuchuu, Y. (2003) Treatment technology of water control substances(IV) treatment technology of anorganic compounds-1. Ind. Water, 543, 22-31.

8) Inamori, Y. (1998) Life Draining Measure, Sangyo Yosui Chosakai, Tokyo, p.120.

9) Hano, T., Takanashi, H., Hirata, M., Urano, K. and
Eto, S. (1997) Removal of phosphorus from wastewater by activated alumina adsorbent. Water Sci. Technol., 35, 39-46.

10) Zhao, D. and Sengupta, A. K. (1997) Ultimate removal of phosphate from wastewater using a new class of polymeric ion exchangers. Water Res., 32, 1613-1625.

11) Tang, W. -P., Shima, O., Ookubo, A. and Ooi, K. (1997) A kinetic study of phosphate adsorption by boehmite. J. Pharm. Sci., 86, 230-235.

12) Haron, M. J., Wasay, S. A. and Tokunaga, S. (1997) Preparation of basic yttrium carbonate for phosphate removal. Water Environ. Res., 69, 1047-1051.

13) Geelhoed, J. S., Hiemstra, T. and Van Riemsdijk, W. H. (1997) Phosphate and sulfate adsorption on gethite: single anion and competitive adsorption. Geochim. Cosmochim. Acta., 61, 2389-2396.

14) Wasay, S. A., Tokunaga, S. and Park, S. W. (1996) Removal of hazardous anions from aqueous solutions by La(III)- and Y(III)-impregnated alumina. Sep. Sci. Technol., 31, 1501-1514.

15) Wasay, S. A., Haron, M. J. and Tokunaga, S. (1996) Adsorption of fluoride, phosphate, and arsenate ions on lanthanum-impregnated silica gel. Water Environ. Res., 68, 295-300.

16) Yamashita, T., Ozawa, Y., Nakajima, N. and Murata, T. (1978) ion exchange properties and uranium adsorption of hydrous titanium(IV) oxide. Nippon $\mathrm{Ka}$ gaku Kaishi, 8, 1057-1061.

17) Weller, S. W. and Hindin, S. G. (1956) The effect of pretreatment on the activity of $\gamma$-alumina. II. Hydrogen-deuterium exchange. J. Phys. Chem., 60, 1506-1512.

18) Peri, J. B. (1965) Infrared and gravimetric study of the surface hydration of $\gamma$-alumina. J. Phys. Chem., 69, 211-219.

19) Kabayama, M., Kawasaki, N., Nakamura, T. and Tanada, S. (2005) Adsorption/desorption characteristics of phosphate ion onto calcined boehmite surface. e-J. Surf. Sci. Nanotech., 3, 63-69.

20) Hill, M. R., Bastow, T. J., Celotto, S. and Hill, A. (2007) Integrated study of the calcination cycle from gibbsite to corundum. Chem. Mater., 19, 28772883.

21) $\mathrm{Xu}$, Y., Ohki, A. and Maeda, S. (2000) Removal of arsenate, phosphate, and fluoride ions by aluminium-loaded Shirasu-zeolite. Toxicol. Environ. Chem., 76, 111-124. 